\title{
Oxy Acetylene Welding Analysis for Plastic Welding of Thermoplastic Polymer Materials
}

\section{Analisa Las Oksi Asitilen untuk Las Plastik Material Polimer Termoplastik}

\author{
Ayeik Abimanyu, Prantasi Harmi Tjahjanti ${ }^{2}$ \\ \{ ayeikabimanyu39@gmail.com ${ }^{1}$ prantasiharmi@ umsida.ac.id ${ }^{2}$ \}
}

Universitas Muhammadiyah Sidoarjo, Indonesia ${ }^{1}$, Universitas Muhammadiyah Sidoarjo, Indonesia ${ }^{2}$

\begin{abstract}
Plastic welding technique is a technique of gluing to workpieces, especially plastic materials. The aim of this research was to join the thermoplastic polymer material using an acetylene oxy welding. The connection method is by melting the electrodes on the workpiece so that the electrodes can fuse to the parent material. The materials used are Polyethylene (PE), Polyvinyl chloride (PVC) and Polypropylene (PP) plastic sheets with the appropriate electrodes from their respective parents. After going through the welding process, the weld results are tested using a dye penetrant. The best results from the dye penetrant are then tested for hardness.
\end{abstract}

Keywords - Acetylene Oxy Welding, PVC, PE, PP, Peneterant Test, Hardness test of thermoplastic polymers

\begin{abstract}
Abstrak.Teknik pengelasan plastik adalah salah satu teknik penyambungan terhadap benda kerja khusus nya material berbahan plastik. Tujuan penelitian adalah menyambung bahan/material polimer termoplastik dengan menggunakan las oksi asitilen. Metode penyambungannya dengan cara melelehkan elektroda kepada benda kerja sehingga elektroda tersebut dapat menyatu terhadap material induknya. Material yang gunakan adalah lembaran plastik Polyethylene (PE), Polyvinyl chloride (PVC) dan Polypropylene (PP) dengan elektroda yang sesuai dari induknya masing-masing. Setelah melalui proses pengelasan, hasil las di uji dengan menggunakan dye penetran. Hasil terbaik dari dye penetran selanjutnya dilakukan uji kekerasan.
\end{abstract}

Kata Kunci - Las Oksi Asetilen, PVC,PE,PP, Uji Peneterant, Uji kekerasan.polimer termoplastik

\section{Pendahuluan}

Sifat dari termoplastik mempunyai ketahanan korosi yang baik dan mempunyai kekuatan rasio yang cukup baik, bahan yang terbuat dari termoplastik dapat dilas dengan cara melelekan material nya lalu di satukan atau dengan bantuan elektroda. Termoplastik dapat dilunakkan dan dibentuk kembali dengan cara pemanasan terhadap lembaran, oleh karna itu polimer termoplastik dapat dilas dengan jenis metode yaitu metode Termal, metode Gesekan dan metode elekromagnetik. [1]

Polimer merupakan salah satu bahan buatan yang bila ditinjau dari proses pembuatannya, dapat diklasifikasikan dalam dua kelompok, yaitu thermoplastics dan thermosetting plastics (Smith, 1998). Kecacatan las terjadi bukan karena kebetulan, tetapi disebabkan oleh beberapa faktor diantaranya yaitu sumber daya manusia yang kurang ahli, sarana dan prasarana yang kurang mendukung, dan kualitas elektroda yang buruk (Heri, 2011). [1]

Plastic welding ialah suatu proses untuk menyatukan material jenis thermoplastik dengan menggunakan suhu aliran tekanan udara panas yang diarahkan ke titik cacat material untuk menyambung dengan cara memanaskan dan melelehkan material termoplastik dengan media bantu pengisi berupa kawat las, penyambungan ini terjadi karena pertemuan antara induk pada penyambungan sejenis dengan induknya, untuk mengetahui suhu pada pengelasan plastik tergantung dari jenis material plastik nya yang akan di las, dan dalam teknik pengelasan plastik ini mempunyai teknik dasar yang perlu di ketahui seperti kecepatan dan tekanan pada pengelasan dengan itu cara untuk mengatasi masalah polimer termoplastik yang retak atau patah tidak menggunakan plastic welding tetapi menggunakan las oksi asitilen. [2]

\section{METODE}

Analisa Las Oksi Asitilen Untuk Las Plastik Material Polimer Termoplastik, Ayeik Abimanyu, pada metode penelitian ini dimulai dari langkah-langkah persiapan dan rancangan yang akan dilakukan dalam proses penelitian, bahan yang di gunakan adalah lembaran PVC (Polivinil choloride), Lembaran PE (Polyethylene), Lembaran PP (Polypropylene) denngan menggunakan kawat las yang sesuai dengan induknya masing-masing, untuk variasian nya akan dilas dengan kawat lasnya seperti Pengelasan PVC Dengan Kawat Las PVC dan Pengelasan PE Dengan Kawat 
Las PE, PVC, PP dan Pengelasan PP Dengan Kawat Las PP, PVC, PE. Setelah pengelasan dilakukan langkah selanjutnya di uji menggunakan dye penetrant dan diuji kekerasaan Universal Hardness Tester QV-700. [2]

Teknik dalam pengelasan plastik ini mahasiswa menggunakan alat las oksi asitilen dimana las tersebut bekerja dari campuran nitrogen dan oksigen sehingga menghasilkan api bertemperature besar maupun kecil, dalam teknik pengelasan plastik ini cukup menggunakan api bertemperatur rendah sesuai dengan titik maksimal bahan material masing-masing. [2]

\section{Hasil dan Pembahasan}

\section{A. Teknik Pengelasan Plastik}

Pada teknik pengelasan metode oksi asitilen ini pada umum nya digunakan untuk pengelasan logam namun dalam pengelasan las plastik menggunakan oksi asitilen perlu untuk di ketahui teknik dalam pengelasan nya, yaitu dengan suhu yang sesuai dengan titik leleh kawat, Suhu panas yang diperoleh sesuai dengan rata-rata titik leleh pada material suhu yang digunakan pada tabel di bawah :

Tabel 4.1 Suhu saat digunakan

\begin{tabular}{ccc}
\hline No & Jenis Material Dan Kawat Las & Suhu \\
\hline 1 & Lembaran PVC + kawat las PVC & $75,3{ }^{\circ} \mathrm{C}$ \\
2 & Lembaran PE + kawat las PE & $127,0^{\circ} \mathrm{C}$ \\
3 & Lembaran PE + kawat las PVC & $84,6{ }^{\circ} \mathrm{C}$ \\
4 & Lembaran PE + kawat las PP & $140,7{ }^{\circ} \mathrm{C}$ \\
5 & Lembaran PP + kawat las PP & $124,9^{\circ} \mathrm{C}$ \\
6 & Lembaran PP + kawat las PE & $120,5^{\circ} \mathrm{C}$ \\
7 & Lembaran PP + kawat las PVC & $86,2^{\circ} \mathrm{C}$
\end{tabular}

Pada tahap pengelasan ini dibutuhkan gambaran atau pandangan yang akan dilakukan pada tahap penelitian, total sampel dari lembaran tersebut sebanyak 21 sampel. Untuk PVC dengan sampel 3, PP dengan 9 sampel, PE dengan 9 sampel. [1]

1. Lembaran PVC (Polivinil klorida)

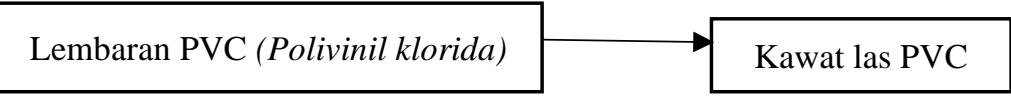

2. Lembaran PE (Polyethylene)

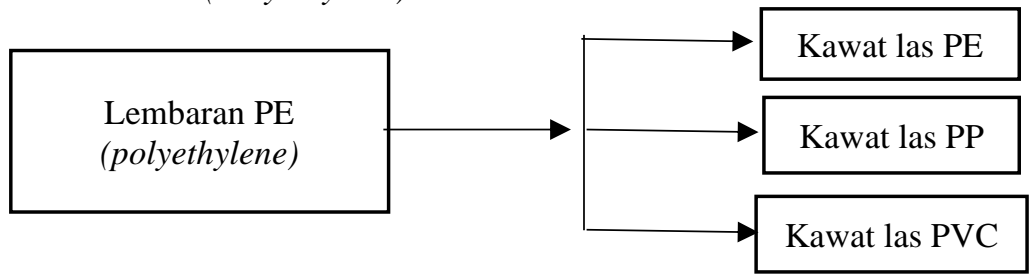

3. Lembaran PP (polypropylene)

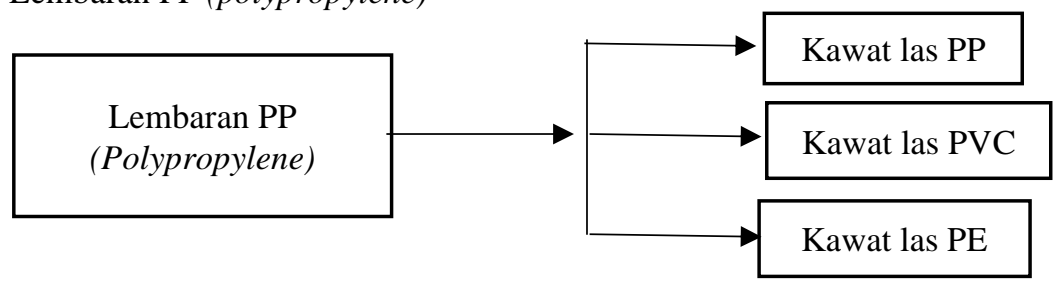

\section{B. Pembuatan Sampel}

1. PVC (Polivinil klorida), pada lembaran pvc ini disiapkan dengan ukuran $30 \mathrm{~cm} \mathrm{x} 30 \mathrm{~cm}$ dan ketebalan 5 $\mathrm{mm}$. PVC ini mempunyai suhu operasi maksimum sekitar $60^{\circ} \mathrm{C}\left(140^{\circ} \mathrm{F}\right)$, salah satu pengaplikasian dari lembaran PVC ini seperti pipa, isolasi kabel plastik, triplek.

2. Material termoplastik lembaran PE (Polyethylene), ukuran pada lembaran ini berukuran $20 \mathrm{~cm} \times 20 \mathrm{~cm}$ dengan ketebalan $10 \mathrm{~mm}$ lembaran ini ketika dipanaskan akan melunak dengan suhu $110^{\circ}$ biasa nya sering digunakan sebagai pipa dan kemasan lainnya. 
3. Material termoplastik lembaran PP (Polypropylene), lembaran ini berukuran Panjang $30 \mathrm{~cm}$ dan panjang 30 $\mathrm{cm}$ dengan ketebalan $5 \mathrm{~mm}$, suhu panas terhadap lembaran ini mempunyai ketahanan mencapai $100{ }^{\circ}$ salah satu contoh pengaplikasian nya ialah digunkan pada tanki, pompa kimia. [1]

\section{Uji Dye Penetrant}

Pada uji dye penetrant ini dilakukan setelah hasil penelitian sudah diselesaikan sampai tahap akhir untuk mengetahui cacat las plastik pada setiap material, dan perlu melakukan uji dye penetrant pada dasar nya pengujian ini untuk mengetahui keretakan atau keroposan yang dapat di deteksi jika keretakan tersebut merembat sampai ke permukaan benda dan juga pada permukaan yang terlalu kasar atau berpori-pori dapat mengakibatkan indikasi yang palsu.

Prosedur pengujian dye penetrant :

- Langkah awal ketika selesai proses pengelasan maka biarkan material tersebut menjadi dingin.

- Langkah kedua bersihkan material menggunakan majun guna untuk membersihkan debu atau kotoran yang menempel pada hasil las, kemudian semprotkan cairan pembersih menggunakan SKC-S Cleaner/Remover, ratakan dan tunggu selama 5 menit sampai mengering pastikan material tersebut bersih dari debu maka ketika sudah kering boleh dibersihkan menggunakan majun.

- Langkah ketiga semprotkan cairan penembus menggunakan SKL-SP2 Red Penetrant, ratakan pada lokasi pengelasan dan tunggu minimal selama 10 menit agar red penetrant dapat meresap pada permukaan hasil las.

- Langkah selanjutnya semprotkan cairan pengembang menggunakan SKD-S2 Developer secara merata pada permukaan hasil las dan tunggu selama 7 menit.

ketika proses akhir sudah dilakukan maka tahap developer akan menarik red penetrant sehingga menunjukan adanya indikasi cacat las pada permukaan. [3]

\section{Uji Kekerasan}

Pada tahap pengujian kekerasan pada hasil las ini maka perlu dilakukan alat bantu untuk pengujian yaitu menggunakan alat uji kekerasan Universal Hardness Tester QV-700. Tahap pengujian ini dilakukan di laboratorium ilmu bahan, satuan dari alat uji ini adalah Brinell, Vickers, Rockwell. Untuk pengujian Tarik dan tekan digunakan untuk UTM atau Universal testing machine. [2]

\section{E. Refensi Jurnal Pengelasan Plastik Dengan Uji Makro Penempang Melintang}

Refensi ini diambil dari Agus Setiawan1), Yudy Surya Irawan2), Anindito Purnowidodo2) Jurusan Teknik Mesin Politeknik Negeri Malang1) Jurusan Teknik Mesin Fakultas Teknik Universitas Brawijaya Malang2) J1. MT.Haryono 167 Malang 65145, Indonesia E-Mail: agussetiawan_72@yahoo.com. dengan judul "PENGARUH TEMPERATUR PELAT LANDASAN SELAMA PROSES FRICTION STIR WELDING TERHADAP KEKUATAN TARIK SAMBUNGAN LAS LEMBARAN HDPE”

Refensi tersebut di ambil dari uji Struktur makro penampang melintang, sambungan las lembaran HDPE pada temperatur pelat landasan. [1]

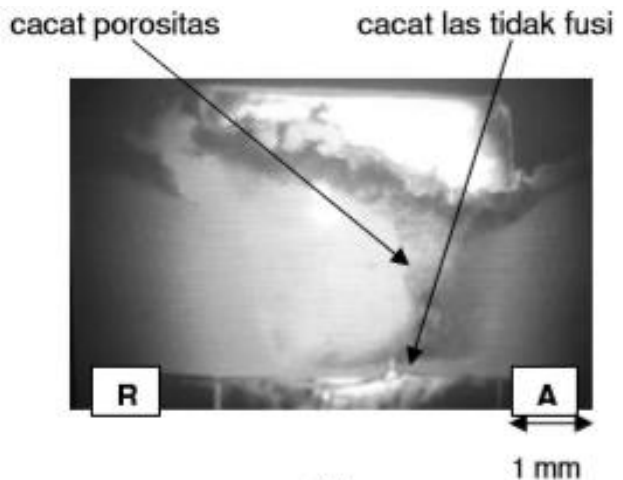

(a)

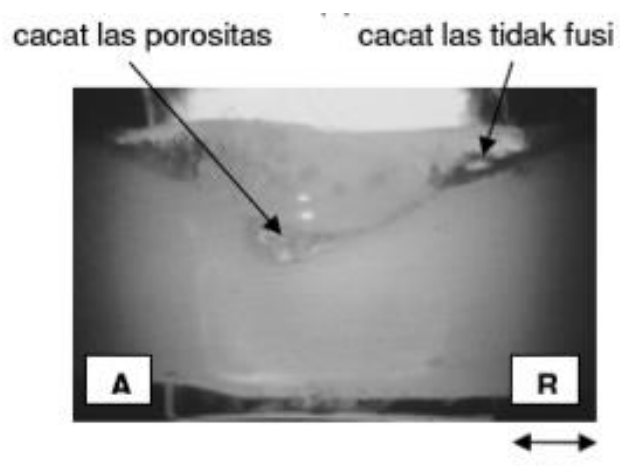

(b)
$1 \mathrm{~mm}$

Gambar 1 Struktur makro penampang melintang sambungan las lembaran HDPE pada temperatur pelat landasan (a) $\mathrm{t}=30 \mathrm{oC}(\mathrm{b}) \mathrm{t}=70 \mathrm{oC}$ 


\section{KESIMPULAN}

Kesimpulan dari penelitian ini untuk mengetahui apakah pengelasan polimer therplasktik menggunakan metode las oksi asitilen ini dapat diterapkan dengan kawat las yang sesuai induk nya dan dengan variasi kawat las masingmasing sehingga dapat di aplikasikan terhadap material industry ataupun peralatan rumah tangga yang masih layak diperbaiki secara teori melalui uji dye penetrant dan uji kekerasan.

\section{UCAPAN TERIMA KASIH}

Dan tak lupa juga ucapan terimakasih kepada semua pihak yang telah turut membantu dalam kelancaran pengerjaan analisis hasil korosi antara lain

1. Ibu Dr.Prantasi Harmi Tjahjanti,S.Si,MT selaku dosen pembimbing

2. Wahyu alfiansyah,ST selaku asistensi laboratorium teknik mesin Universitas Muhammadiyah Sidoarjo

\section{REFERENSI}

[1] Agus Setiawan1), Y. S. (2011). Pengaruh Temperatur Pelat Landasan Selama Proses Friction Stir Welding Terhadap Kekuatan Tarik Sambungan Las Lembaran HDPE. Jurnal Rekayasa Mesin Vol.2, No. 3 Tahun $2011: 232-240,9$.

[2] Arie Indra Rusmana, S. (2018). MELAKUKAN PENETRANT TEST (PT) C.24LAS01.034.01 . jakarta selatan: DIREKTORAT JENDERAL PEMBINAAN PELATIHAN DAN PRODUKTIVITAS DIREKTORAT BINA STANDARDISASI KOMPETENSI DAN PELATIHAN KERJA .

[3] Magdalena Feby Kumayasari, A. I. (2017). Studi Uji Kekerasan Rockwell Superficial VS Micro Vickers . JURNAL TEKNOLOGI PROSES DAN INOVASI INDUSTRI, 85-89. 